\title{
Effect of Salinities on Gastric Emptying and Nutrient Absorption of Tiger Grouper $\times$ Giant Grouper (Epinephelus fuscoguttatus $\times$ E. lanceolatus) Hybrid
}

(Kesan Kemasinan terhadap Pengosongan Gastrik dan Penyerapan Nutrien pada Hibrid Kerapu Harimau $\times$ Kerapu Kertang (Epinephelus fuscoguttatus $\times$ E. lanceolatus)

\author{
NoORASHIKIN Md NoOR, Simon Kumar DAS*, ZAidi CHe CoB \& MAZlan AbD. GHAFFAR
}

\begin{abstract}
The effects of salinity on the gastric emptying time (GET) and absorption of nutrient along the alimentary tract of tiger grouper $(T G) \times$ giant grouper $(G G)$ (Epinephelus fuscoguttatus $\times$ E. lanceolatus) hybrid were studied. Juveniles TG $\times G G$ hybrid grouper $(10.0 \pm 0.5 \mathrm{~cm}$ total length; $50.5 \pm 2.0 \mathrm{~g})$ were reared in different salinities $(10,15,20,25$ and 30 parts per thousand (ppt)) and fed with commercial pellet diet during the 60-day experimental period. The fish were then slaughtered sequentially at different time intervals after initial feeding to obtain GET. Our results showed that low salinity (10-20 ppt) lead to a shorter GET in the hybrid grouper. The shortest and longest GETs were observed in 15 ppt (12 h) and 30 ppt (18 h) treatments, respectively. Apparent digestibility coefficient $(A D C)$ using ash contents was measured to determine the absorption of nutrient in each treatment. The absorption of macronutrient in TGXGG hybrid grouper was increased as the salinity decreased. The highest absorption occurred in 15 ppt (72\% protein, $75 \%$ lipid, $68 \%$ carbohydrate and $74 \%$ energy) while the lowest absorption occurred in 30 ppt (59\% protein, $64 \%$ lipid, 34\% carbohydrate and 55\% energy). The findings of this study suggested that 15 ppt salinity facilitates faster digestion and maximize the nutrient absorption of $T G \times G G$ hybrid and may enhance the growth rate of this newly developed grouper species.
\end{abstract}

Keywords: Aquaculture; digestion; hybrid grouper; nutrient absorption; salinity

\section{ABSTRAK}

Pengaruh tahap kemasinan pada masa pengosongan gastrik (GET) dan penyerapan nutrien di dalam saluran pencernaan hibrid kerapu harimau $(T G) \times$ kerapu kertang $(G G)$ (Epinephelus fuscoguttatus $\times$ E. lanceolatus) telah dikaji. Juvenil kerapu hibrid TGXGG (10.0 $\pm 0.5 \mathrm{~cm}$ panjang dan $50.5 \pm 2.0$ gram berat awal) dikultur dalam kemasinan yang berbeza $(10,15,20,25$ dan 30 bahagian per seribu (ppt)) dan diberi pelet komersial semasa 60 hari tempoh eksperimen. Ikan disembelih mengikut urutan pada masa yang berlainan selepas makanan pertama diberi untuk mengira GET. Kesan kemasinan yang rendah (10-20 ppt) telah mengurangkan tempoh GET kerapu hibrid TGXGG. Keputusan kajian menunjukkan bahawa masa pengosongan gastrik paling pendek (GET) dan paling lama masing-masing adalah pada 15 ppt (12 jam) dan 30 ppt (18 jam). Pekali pencernaan yang ketara (ADC) menggunakan kandungan abu sebagai sampel rujukan diukur untuk menentukan penyerapan nutrien dalam setiap rawatan. Penyerapan makronutrien yang meningkat dalam kerapu hibrid $T G \times G G$ dapat diperhatikan apabila kemasinan berkurangan. Penyerapan yang tinggi dapat dilihat dalam kemasinan yang rendah iaitu 15 ppt (72\% protein, lipid 75\%, karbohidrat $68 \%$ dan tenaga $74 \%$ ) manakala penyerapan paling rendah berlaku dalam 30 ppt (59\% protein, lipid 64\%, karbohidrat 34\% dan tenaga 55\%). Penemuan mendedahkan bahawa kemasinan 15 ppt dapat mempercepatkan proses pencernaan dan penyerapan nutrien yang maksimum dan seterusnya menyumbang kepada tumbesaran yang lebih cepat dalam spesis ikan kerapu yang baru dibangunkan ini.

Kata kunci: Akuakultur; kemasinan; kerapu hibrid; pencernaan; penyerapan nutrien

\section{INTRODUCTION}

Salinity affects the feed intake, feed requirements, feed conversion ratio, digestibility and other physiological functions in fish (Sutthinon et al. 2015). Studies showed that a significant effect on digestibility conditioned to different salinities are observed in different fish species such as milkfish Chanos chanos (Feraris et al. 1986), gilthead sea bream Sparus aurata (Conides et al. 1997) and black bream Acanthopagrus butcheri (Partridgen \& Jenkins 2002). As many of the world's cultured species are euryhaline, information on the effects of salinity on nutritional physiology can therefore assist on the understanding of the physiology of euryhaline fish species such as groupers.

Groupers are among the cultivable marine fish which are considered to grow better in the euryhaline environment especially during juvenile stages (Sutthinon et al. 2015). Studies have been carried on the effects of salinity on the growth of grouper species such as, the optimum salinity for better growth of giant grouper E. lanceolattus was 15 
- 25 ppt (Singhabun \& Kummee 2015) and orange spotted grouper, E. coiodes was 12 - 18 ppt (Su-jiu et al. 2011). However, research on the salinity effects on growth and digestion physiology of newly developed TG×GG hybrid grouper is yet to be explored.

Alimentary tract plays a critical role in the acquisition of food with subsequent absorption of important nutrients (Eusebio et al. 2004). In general, digestion studies involved the measurement of the time for complete gastric emptying and absorption of different nutrients (Wetherbee et al. 1987). This depend on several factors such as fish size, water temperature, feeding frequency, food quantity and quality as well as salinity (Specziar 2002; Temming \& Herrmann 2001; Wuenschel \& Werner 2004). Determination of gastric emptying in cultivable fish species is important for aquaculture, where estimation of species' food consumption is needed for management purposes. Also, studies on the food passage through the alimentary tract plays an important role for the development and formulation of an efficient food supply and dietary for captive and cultured species.

Therefore, this study was conducted to investigate the effects of salinity in the GET of TGXGG hybrid grouper juvenile. This was done by collecting data on the nutrient absorption along the alimentary tract of TG $\times$ GG hybrid grouper cultured in different salinities $(10,15,20,25$ and $30 \mathrm{ppt}$ ). This investigation will provide the first account of some basic parameters of digestion physiology in $\mathrm{TG} \times \mathrm{GG}$ hybrid grouper.

\section{MATERIALS AND METHODS}

\section{SAMPLE COLLECTION AND EXPERIMENTAL SETUP}

TG $\times$ GG hybrid grouper $(\mathrm{N}=225$, length $=10.0 \pm 0.5 \mathrm{~cm}$, weight $=50.5 \pm 2.0 \mathrm{~g}$ ) was transported from a local hatchery of Banting, Selangor ( $2^{\circ} 0^{\prime} \mathrm{N}, 101^{\circ} 0$ ' $\left.\mathrm{E}\right)$ to the marine science laboratory of Universiti Kebangsaan Malaysia, Bangi, Selangor. Fish was distributed randomly among three stocking tanks $(1.96 \times 1.02 \times 0.61 \mathrm{~m} ; 1200 \mathrm{~L})$ supplied with running sea water at $30 \mathrm{ppt}$ salinity at $26^{\circ} \mathrm{C}$. The fish (75 fish/tank) were fed the same commercial pellet (Star feed: Marine 9982/84, CP Group, Malaysia) used in the hatchery. Acclimatization was done for two weeks before the fish were randomly transferred to 15 experimental tanks $(123 \times 63 \times 46 \mathrm{~cm}, 356 \mathrm{~L})$ with 15 fish per tank.

Prior to the GET experiments, fish were not fed for $24 \mathrm{~h}$ to allow a complete emptying of the stomach. Once the fish started to feed and defecate, the experiment was started for a 60-day experimental period. Three replicates were used for every experimental salinity change $(10,15$, 20,25 and $30 \mathrm{ppt}$ ). The salinity level of natural seawater was determined with a reflecto-salinometer (S-10E; Atago Co., Ltd, Washington, DC, USA) and the salinity of each treatment was controlled by mixing sea water and fresh water at a rate of 2 ppt per day until the experimental salinity has reached. During the 60-day experiment period, the fish were manually fed with the commercial pellet twice daily (0800 and 1500 h) (De et al. 2016, 2014) until apparent satiation was reached where the fish stopped feeding and pellets remained at the bottom of the tank. Uneaten food was then measured by siphoning pellets out of the tanks and drying them immediately to a constant mass in an oven at $60^{\circ} \mathrm{C}$ for $24 \mathrm{~h}$. The amount of food consumed during each meal was calculated as the difference between the mass of the food offered and that of the uneaten food. During this period, all tanks were maintained on a $12 \mathrm{~h}$ light: $12 \mathrm{~h}$ dark photoperiod.

\section{GASTRIC EMPTYING TIME EXPERIMENT}

The satiated fish were then anaesthetized using tricaine methanesulphonate (MS-222 Sandoz) $\left(0.22 \mathrm{ml} \mathrm{L}^{-1}\right.$ in $3 \mathrm{~L}$ of sea water) for $10 \mathrm{~min}$ and an incision was made on the anterior spine. Observations were made at $0,2,4,8,12$, 16,20 and $24 \mathrm{~h}$ after feeding (three fish were used at each experimental time). Fish were measured (total length with $1 \mathrm{~mm}$ precision) and weighed (wet weight with $0.01 \mathrm{~g}$ precision). Also, the stomach contents were weighed (wet weight with a $0.001 \mathrm{~g}$ precision).

\section{NUTRIENT ABSORPTION}

The diet and alimentary tract of fish were weighed to the nearest $\mathrm{mg}$ and further analyzed according to methods by AOAC (1995). The alimentary tract of $\mathrm{TG}^{\times} \mathrm{GG}$ hybrid grouper (typical carnivorous type; shorter comprises with pyloric caeca) were then removed and cut into four sections, namely stomach, anterior intestine, mid intestine and posterior intestine in order to test the food movement and nutrient absorption effectively (Firdaus-Nawi et al. 2013). Following that, the contents were placed into sample container $(50 \mathrm{~mL})$ and homogenized before kept at $-16^{\circ} \mathrm{C}$ and freeze dried at $-60^{\circ} \mathrm{C}$ for three days (Christ Alpha 1-2 L Dplus, Shropshire, UK). The analysis was performed on three samples (replicates) from the alimentary tract. For moisture content, the measurement was done by calculating the weight loss after the samples were kept in the freezer (Christ Alpha 1 - 2 L Dplus, Shropshire, UK) at -40 to $-60^{\circ} \mathrm{C}$ for $3-4$ days depending on the size of the samples. The dried samples were ground to a homogenous powder using a mortar and pestle and kept in small glass vials in desiccators for further biochemical analyses. The inorganic matter or ash content of each part of gut samples was determined using a furnace (WiseThermR FM Digital Muffle Furnaces, Nabertherm, Germany) at $450^{\circ} \mathrm{C}$ for $3 \mathrm{~h}$. The ash content was calculated by the difference between initial and final dry weight of the sample. Total nitrogen content of diet and gut content was measured using a CHNS analyzer (EAGER 300, Thermo Finnigan, Italy). Protein was calculated from nitrogen content multiplied by the factor of 6.25 (Jones 1931). The lipid content of diet and gut content was measured by petroleum ether extraction using a Soxtec System (2055 Soxtec Avanti; Foss Teacator, Hoganas, Sweden). Carbohydrate levels of dry weight were calculated by the formula following Xin et al. (2008): 
Carbohydrate $(\%)=100 \%-(\operatorname{protein} \%+\operatorname{lipid} \%+\operatorname{ash} \%)$ Energy content (kJ g-1) (gross energy, GE) of the samples was determined by bomb calorimeter (IKAR C200 Calorimeter System; IKAR Werke GmbH \& Co. KG, Staufen, Germany). Absorption of nutrient in the four sections along the alimentary tract was calculated by the apparent digestibility coefficient (ADC):

$$
\begin{aligned}
\operatorname{ADC}(\%)= & 100 \% \times\left[1-\left(\text { Ash }_{\mathrm{a}}: \text { Nutrient }_{\mathrm{a}} \div\right.\right. \\
& \text { Ash } \left.\left._{\mathrm{b}}: \text { Nutrient }_{\mathrm{b}}\right)\right],
\end{aligned}
$$

based on ash content of samples collected from adjacent segments of the alimentary tract (Das et al. 2014; Maynard et al. 1979).

\section{STATISTICAL ANALYSIS}

All nutrient data, except for experimental meal, were tested for normality (Anderson-Darling test) and homogeneity of variances (Levene test) using Minitab statistical software version 14. Data were found to be normally distributed, therefore, one-way ANOVA tests were employed for multiple comparisons of means. To compare nutrient concentrations in experimental meals and feces, a MannWhitney test was used to account for the small sample size. The level of significance used was at $p=0.05$.

\section{RESULTS}

\section{GASTRIC EMPTYING TIME EXPERIMENT}

GET decreased as the salinity increased from 25 to $30 \mathrm{ppt}$ (Figure 1). The faster gastric emptying was observed at 15

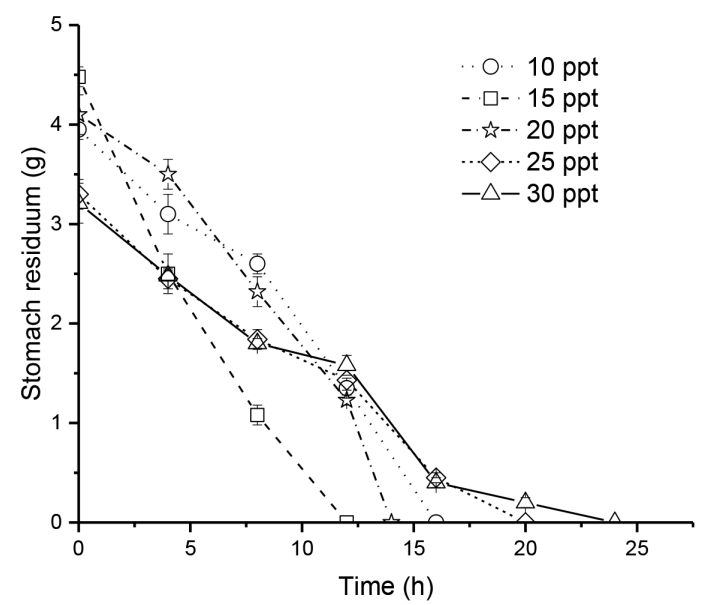

FIGURE 1. Gastric emptying time (h) in TGXGG hybrid grouper $( \pm \mathrm{SE}, n=6)$ at five different salinities (ppt) ppt which takes $12 \mathrm{~h}$ to completely digest the food item. On the other hand, the longest gastric emptying occurred at $30 \mathrm{ppt}$ where fish completely digested the food after $24 \mathrm{~h}$.

\section{NUTRIENT ABSORPTION}

Experimental food pellets contained less ash (39.2\%) and moisture $(9.4 \%)$ (Table 1) than faeces of fish reared in different salinities 10,15 and $20 \mathrm{ppt}$ and 25 to $30 \mathrm{ppt}$ salinity (Table 2). Meanwhile, stomach contents of fish reared in all salinities contained less ash content than anterior and posterior intestines (Table 3 ). The ash content increases from stomach towards the posterior intestine with the significantly $(p<0.05)$ highest in $15 \mathrm{ppt}(36.8 \%)$ salinity while the lowest in $30 \mathrm{ppt}$ (33.1\%). In addition, ash content increased progressively towards posterior intestine in decreasing salinity with the significantly $(p<0.05)$ highest in $15 \mathrm{ppt}(56.2 \%)$ and lowest in $30 \mathrm{ppt}(52.5 \%)$. It was also observed that the moisture content decreased significantly $(p<0.05)$ with increasing salinity with the significantly lowest in $15 \mathrm{ppt}(41.05 \%)$ while the significantly highest in 30 ppt (44.5\%) (Table 3).

Protein was the largest organic matter present in the experimental pellet (42.24\%), with less lipid (11.1\%) and low carbohydrate level $(0.50 \%)$. In faeces of TGXGG hybrid grouper cultured in different salinities, the values for protein and lipid were reduced; (Table 2). Stomach contents of TGXGG hybrid grouper cultured in different salinities contained higher protein and lipid content than the intestine (Table 3$)$ with the significantly $(p<0.05)$ highest protein content in $15 \mathrm{ppt}(50.1 \%)$ and significantly $(p<0.05)$ lowest in $30 \mathrm{ppt}(41.9 \%)$. Carbohydrate fractions were normally $<1 \%$ of dry mass for all portions of the alimentary tract of TG $\times \mathrm{GG}$ hybrid grouper cultured in different salinities (Table 3).

The highest energy content was observed in faeces of TGXGG hybrid cultured in $15 \mathrm{ppt}(12.8 \mathrm{~kJ} / \mathrm{g})$ and the lowest was observed in $30 \mathrm{ppt}(10.3 \mathrm{~kJ} / \mathrm{g})$ (Table 2). This trend was also observed in the energy content for different portions of the gut in TG $\times$ GG hybrid grouper cultured in different salinities (Table 3 ).

For TG $\times$ GG hybrid grouper cultured in $15 \mathrm{ppt}$, approximately $15 \%$ protein, $35 \%$ total lipids and $25 \%$ carbohydrate appeared to have been absorbed in passage between the stomach and the anterior intestine (Figure 2(A)-2(C)). An apparent negative absorption between samples from the stomach and anterior intestine was observed for carbohydrate analyzed (Figure 2(A)-2(C)). In the passage of the remaining nutrients from mid-intestine to posterior intestine, approximately $40 \%$ protein, $50 \%$ total lipids and $40 \%$ carbohydrate were absorbed (Figure 2(A)2(C)). Meanwhile, for TGXGG hybrid grouper cultured in 30

TABLE 1. Nutrient analysis (mean $\pm \mathrm{SE}$ ) of experimental pellet used

\begin{tabular}{cccccc}
\hline Ash (\%) & Moisture (\%) & Protein $(\%)$ & Lipid $(\%)$ & Carbohydrate $(\%)$ & Energy $(\mathrm{kJ} / \mathrm{g})$ \\
\hline $39.2 \pm 0.15$ & $9.4 \pm 0.33$ & $42.24 \pm 0.75$ & $11.1 \pm 0.37$ & $0.50 \pm 0.01$ & $14.6 \pm 0.31$ \\
\hline
\end{tabular}


TABLE 2. Nutrient analysis (mean $\pm \mathrm{SE} ; n=6$ ) of faeces of TG×GG hybrid in different salinities. Mean values within the same column having the same superscript are not significantly different $(p>0.05)$

\begin{tabular}{ccccccc}
\hline Salinity (ppt) & Ash $(\%)$ & Moisture $(\%)$ & Protein $(\%)$ & Lipid $(\%)$ & Carbohydrate $(\%)$ & Energy $(\mathrm{kJ} / \mathrm{g})$ \\
\hline 10 & $53.2 \pm 0.30^{\mathrm{b}}$ & $67.2 \pm 0.5^{\mathrm{b}}$ & $23.0 \pm 0.30^{\mathrm{b}}$ & $3.6 \pm 0.17^{\mathrm{b}}$ & $0.53 \pm 0.04^{\mathrm{a}}$ & $12.7 \pm 0.5^{\mathrm{b}}$ \\
15 & $52.5 \pm 0.2^{\mathrm{b}}$ & $67.0 \pm 0.5^{\mathrm{b}}$ & $23.5 \pm 0.33^{\mathrm{b}}$ & $4.0 \pm 0.22^{\mathrm{b}}$ & $0.55 \pm 0.05^{\mathrm{a}}$ & $12.8 \pm 0.48^{\mathrm{b}}$ \\
20 & $53.1 \pm 0.2^{\mathrm{b}}$ & $67.0 \pm 0.4^{\mathrm{b}}$ & $23.3 \pm 0.31^{\mathrm{b}}$ & $3.8 \pm 0.23^{\mathrm{b}}$ & $0.55 \pm 0.04^{\mathrm{a}}$ & $12.5 \pm 0.48^{\mathrm{b}}$ \\
25 & $55.8 \pm 0.35^{\mathrm{c}}$ & $68.5 \pm 0.22^{\mathrm{c}}$ & $21.0 \pm 0.40^{\mathrm{c}}$ & $3.0 \pm 0.25^{\mathrm{c}}$ & $0.51 \pm 0.03^{\mathrm{b}}$ & $10.6 \pm 0.36^{\mathrm{c}}$ \\
30 & $56.2 \pm 0.28^{\mathrm{c}}$ & $69.0 \pm 0.75^{\mathrm{c}}$ & $20.6 \pm 0.37^{\mathrm{c}}$ & $2.8 \pm 0.30^{\mathrm{c}}$ & $0.50 \pm 0.02^{\mathrm{a}}$ & $10.3 \pm 0.40^{\mathrm{c}}$ \\
\hline
\end{tabular}

TABLE 3 . Nutrient analysis of digesta ( $\%$ dry weight \pm SE) along the alimentary tract section. Mean values $(n=6)$ within the same column of a given salinity having the same superscript are not significantly different $(p>0.05)$

\begin{tabular}{|c|c|c|c|c|c|c|}
\hline & Ash & Moisture & Protein & Lipid & Carbohydrate & Total energy $(\mathrm{kJ} / \mathrm{g})$ \\
\hline \multicolumn{7}{|l|}{ (A) $10 \mathrm{ppt}$} \\
\hline Stomach & $35.0 \pm 0.45^{\mathrm{a}}$ & $69.5 \pm 0.15^{\mathrm{a}}$ & $45.4 \pm 0.25^{\mathrm{a}}$ & $10.7 \pm 0.55^{\mathrm{a}}$ & $0.55 \pm 0.01^{\mathrm{a}}$ & $17.0 \pm 0.35^{\mathrm{a}}$ \\
\hline Mid intestine & $47.8 \pm 0.44^{\mathrm{a}}$ & $50.3 \pm 0.15^{\mathrm{a}}$ & $37.8 \pm 0.40^{\mathrm{a}}$ & $7.5 \pm 0.28^{\mathrm{a}}$ & $0.50 \pm 0.02^{\mathrm{a}}$ & $14.0 \pm 0.40^{\mathrm{a}}$ \\
\hline Posterior intestine & $54.2 \pm 0.50^{\mathrm{a}}$ & $42.6 \pm 0.23^{\mathrm{a}}$ & $27.6 \pm 0.55^{\mathrm{a}}$ & $5.0 \pm 0.58^{\mathrm{a}}$ & $0.42 \pm 0.02^{\mathrm{a}}$ & $9.5 \pm 0.40^{\mathrm{a}}$ \\
\hline \multicolumn{7}{|l|}{ (B) $15 \mathrm{ppt}$} \\
\hline Stomach & $36.8 \pm 0.45^{\mathrm{b}}$ & $67.5 \pm 0.66^{\mathrm{b}}$ & $50.1 \pm 0.25^{\mathrm{b}}$ & $11.6 \pm 0.25^{b}$ & $0.62 \pm 0.02^{\mathrm{b}}$ & $18.2 \pm 0.25^{\mathrm{b}}$ \\
\hline Anterior intestine & $40.4 \pm 0.42^{\mathrm{b}}$ & $58.9 \pm 0.55^{\mathrm{b}}$ & $46.4 \pm 0.15^{\mathrm{b}}$ & $10.0 \pm 0.25^{\mathrm{b}}$ & $0.65 \pm 0.03^{\mathrm{b}}$ & $16.8 \pm 0.24^{\mathrm{a}}$ \\
\hline Mid intestine & $48.7 \pm 0.51^{\mathrm{b}}$ & $52.3 \pm 0.53^{\mathrm{b}}$ & $45.7 \pm 0.28^{b}$ & $8.3 \pm 0.33^{\mathrm{b}}$ & $0.70 \pm 0.03^{\mathrm{b}}$ & $15.7 \pm 0.25^{\mathrm{b}}$ \\
\hline Posterior intestine & $56.2 \pm 1.04^{\mathrm{b}}$ & $44.5 \pm 0.60^{\mathrm{b}}$ & $30.9 \pm 0.20^{\mathrm{b}}$ & $6.3 \pm 0.20^{\mathrm{b}}$ & $0.62 \pm 0.01^{\mathrm{b}}$ & $12.5 \pm 0.25^{\mathrm{b}}$ \\
\hline \multicolumn{7}{|l|}{ (C) $20 \mathrm{ppt}$} \\
\hline Stomach & $35.4 \pm 0.43^{\mathrm{c}}$ & $68.1 \pm 0.44^{\mathrm{c}}$ & $48.0 \pm 0.15^{\mathrm{c}}$ & $11.1 \pm 0.30^{\mathrm{c}}$ & $0.58 \pm 0.02^{\mathrm{b}}$ & $17.5 \pm 0.30^{\mathrm{c}}$ \\
\hline Anterior intestine & $39.7 \pm 0.38^{c}$ & $57.1 \pm 0.48^{\mathrm{b}}$ & $44.5 \pm 0.20^{c}$ & $9.2 \pm 0.33^{c}$ & $0.60 \pm 0.02^{\mathrm{b}}$ & $18.3 \pm 0.33^{\mathrm{c}}$ \\
\hline Mid intestine & $48.2 \pm 0.46^{\mathrm{c}}$ & $51.7 \pm 0.40^{\mathrm{c}}$ & $38.4 \pm 0.28^{c}$ & $7.8 \pm 0.25^{\mathrm{c}}$ & $0.62 \pm 0.02^{\mathrm{c}}$ & $17.0 \pm 0.35^{\mathrm{c}}$ \\
\hline Posterior intestine & $55.8 \pm 1.05^{\mathrm{c}}$ & $43.4 \pm 0.41^{\mathrm{c}}$ & $30.2 \pm 0.30^{c}$ & $5.6 \pm 0.30^{c}$ & $0.57 \pm 0.03^{\mathrm{b}}$ & $12.2 \pm 0.28^{\mathrm{b}}$ \\
\hline \multicolumn{7}{|l|}{ (D) $25 \mathrm{ppt}$} \\
\hline Stomach & $34.0 \pm 0.44^{\mathrm{d}}$ & $70.8 \pm 0.40^{\mathrm{d}}$ & $44.2 \pm 0.20^{\mathrm{d}}$ & $10.0 \pm 0.35^{\mathrm{d}}$ & $0.53 \pm 0.02^{\mathrm{b}}$ & $16.2 \pm 0.25^{\mathrm{d}}$ \\
\hline Anterior intestine & $38.2 \pm 0.48^{\mathrm{d}}$ & $55.3 \pm 0.43^{\mathrm{d}}$ & $39.1 \pm 0.25^{\mathrm{d}}$ & $7.8 \pm 0.28^{\mathrm{d}}$ & $0.47 \pm 0.03^{c}$ & $16.8 \pm 0.25^{\mathrm{d}}$ \\
\hline Mid intestine & $45.2 \pm 0.55^{\mathrm{d}}$ & $49.0 \pm 0.45^{\mathrm{d}}$ & $34.7 \pm 0.28^{\mathrm{d}}$ & $6.7 \pm 0.27^{d}$ & $0.42 \pm 0.02^{\mathrm{c}}$ & $13.0 \pm 0.26^{\mathrm{d}}$ \\
\hline Posterior intestine & $53.1 \pm 0.88^{\mathrm{d}}$ & $41.5 \pm 0.50^{\mathrm{d}}$ & $25.3 \pm 0.28^{\mathrm{d}}$ & $4.3 \pm 0.25^{\mathrm{d}}$ & $0.34 \pm 0.02^{\mathrm{c}}$ & $8.5 \pm 0.28^{\mathrm{d}}$ \\
\hline \multicolumn{7}{|l|}{ (E) $30 \mathrm{ppt}$} \\
\hline Stomach & $33.1 \pm 0.40^{\mathrm{e}}$ & $72.1 \pm 0.38^{\mathrm{e}}$ & $41.9 \pm 0.44^{\mathrm{e}}$ & $9.6 \pm 0.25^{\mathrm{d}}$ & $0.50 \pm 0.03^{\mathrm{b}}$ & $15.0 \pm 0.27^{\mathrm{e}}$ \\
\hline Anterior intestine & $40.0 \pm 0.43^{\mathrm{e}}$ & $54.8 \pm 0.42^{\mathrm{e}}$ & $38.0 \pm 0.50^{\mathrm{e}}$ & $7.6 \pm 0.33^{\mathrm{d}}$ & $0.45 \pm 0.03^{c}$ & $15.0 \pm 0.25^{\mathrm{e}}$ \\
\hline Mid intestine & $45.0 \pm 0.38^{\mathrm{e}}$ & $48.3 \pm 0.43^{\mathrm{e}}$ & $30.6 \pm 0.50^{\mathrm{e}}$ & $6.3 \pm 0.35^{\mathrm{d}}$ & $0.35 \pm 0.03^{c}$ & $10.6 \pm 0.28^{\mathrm{e}}$ \\
\hline Posterior intestine & $52.5 \pm 0.52^{\mathrm{e}}$ & $41.0 \pm 0.44^{\mathrm{e}}$ & $18.2 \pm 0.55^{\mathrm{e}}$ & $3.8 \pm 0.38^{\mathrm{d}}$ & $0.25 \pm 0.05^{\mathrm{d}}$ & $6.0 \pm 0.30^{\mathrm{e}}$ \\
\hline
\end{tabular}

ppt, approximately $25 \%$ protein, $20 \%$ total lipids and $5 \%$ carbohydrate appeared to have been absorbed in passage between the stomach and the anterior intestine (Figure 2(A)-2(C)). From mid-intestine to posterior intestine, approximately $45 \%$ protein, $30 \%$ total lipids and $20 \%$ carbohydrate were absorbed (Figure 2(A)-2(C)).

Between the stomach and posterior intestine, the overall effect of absorption in the different zones showed that the highest absorption observed in $15 \mathrm{ppt}$ and the lowest in 30 ppt (Figure 2(A)-2(D)). The general effect of absorption between the stomach and posterior intestine in TG $\times$ GG hybrid grouper showed that $28 \%$ protein, $25 \%$ lipid, $32 \%$ carbohydrate and $26 \%$ energy had been absorbed in 30 ppt while higher nutrient was absorbed in 15 ppt where $41 \%$ protein, $36 \%$ lipid, $66 \%$ carbohydrate and $45 \%$ energy had been absorbed (Figure 2(A)-2(D)).

\section{DISCUSSION}

In the present study, gastric emptying was found to be highly salinity dependent. It was observed that at 25 and $30 \mathrm{ppt}$, longer time is needed to empty the digestive tract indicating the fish might be in stressful condition. Comparably, a study showed that feeding rates of European seabass, Dicentrarchus labrax and grey snapper, Lutjanus griseus decreased with decreasing salinity (Wuenschel \& Werner 2004). As these fishes are euryhaline similar to grouper hybrid, the author suggests that higher metabolic occurs at higher salinity (Wuenschel \& Werner 2004). The fish operate at higher efficiency and maintain high growth rates at lower salinities (15-20 ppt). This provides important implications when considering habitat use constrains whereby estuarine nurseries will provide conditions that allow faster GET than the coastal nurseries. 

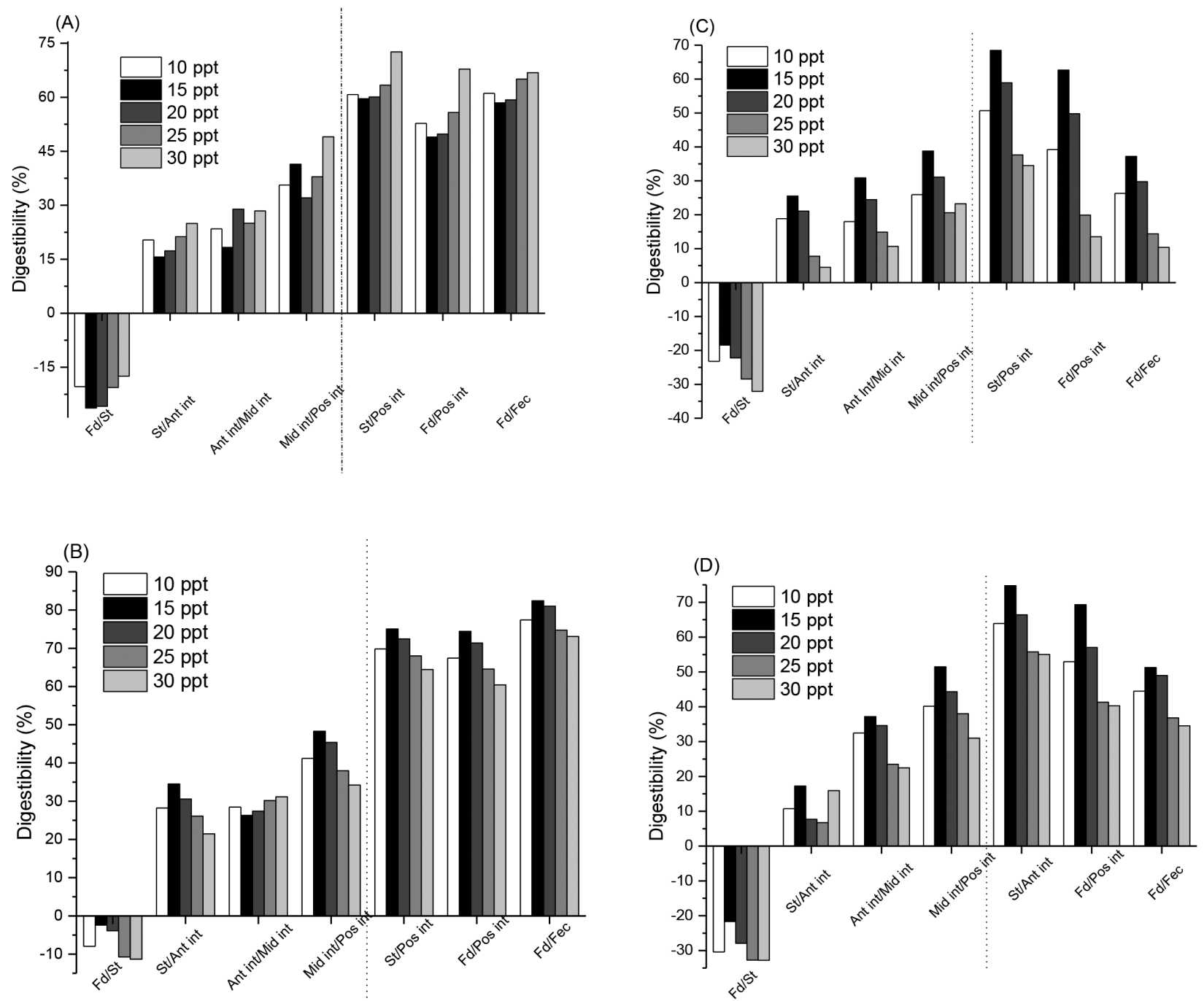

FIGURE 2. Apparent digestibility coefficient (ADC, \% dry weight) for (A) protein, (B) lipid, (C) carbohydrate and (D) energy between adjoining regions along the alimentary tract of TG×GG hybrid grouper. Bars to the right of the vertical dotted line are values for non-adjoining gut sections along the alimentary tract $(\mathrm{Fd}=$ food, $\mathrm{St}=$ stomach, Ant int=anterior intestine, Mid int=mid intestine, Pos int=posterior intestine, $F e c=$ faeces)

Furthermore, low salinity gives a better effect to juvenile sole, Solea sole where faster GET observed at $15 \mathrm{ppt}$ (14 h) while higher salinity $35 \mathrm{ppt}$ slower the GET (16 h) in $S$. senegalensis (Vinagre et al. 2007).

From the results, it is observed that the nutrient absorption is higher as the salinity decreased with the highest nutrient absorption occurred at $15 \mathrm{ppt}$ and lowest at $30 \mathrm{ppt}$. In all salinities, the pattern of nutrient changes (protein, lipids and energy) are the same as it passed along the alimentary tract. Nutrient content changes because of the addition of mucus and enzymes during the digestion process (Mazlan \& Groove 2003). The amount of protein, lipids and energy decreased along the tract. This is due to the nutrient absorption occurred higher in the initial gut where the degradation process takes place in the stomach and the process continues in the anterior and posterior intestine (Mazlan \& Groove 2003). The decreased amount of protein, lipids and energy along the gut have been documented in rainbow trout Onchorhynchus mykiss (Austreng 1978), Atlantic cod Gadus morhua (Lied 1982), whiting Merlangius merlangus (Mazlan \& Groove 2003) and archerfish Toxotes jaculatrix (Das et al. 2014). Lipids and proteins were not reserved or removed from the stomach compare to the other nutrients.

Protein was absorbed in the anterior intestine, where pyloric caeca is situated. The caeca increase the volume of the anterior midgut and the absorptive area of the digestive tract which is important for protein absorption (García-Meilán et al. 2016). The results are in accordance with findings in the European sea bass Dicentrarchus labrax (Zambonino-Infante et al. 2017) and Atlantic cod Gadus morhua (Hamre et al. 2011) where absorption of protein happened in the pyloric caeca. More than $30 \%$ of the protein was absorbed between the stomach and rectum compared to other nutrients in TGXGG hybrid grouper as the stomach is a highly efficient organ for degrading proteins 
(Ikeda et al. 2017). Further, the fecal analysis measurement supported that the protein may leach into the experimental water through its feces. Furthermore, it is suggested that the carbohydrate level raised in the anterior intestine was probably because of the emission of mucus (Gisbert et al. 2009; Mazlan \& Groove 2003). However, carbohydrate digestion has received less attention than the protein and lipid due to the low carbohydrate content of the pellet.

Lipid absorption happened in the anterior intestine, where the pyloric caeca is situated where it is important for lipid absorption besides protein. Pancreatic lipase is secreted in the caeca (Borlongan 1990; García-Meilán et al. 2016). The presence of pancreatic lipase activity in fish has been described in the stomach tissue of catfish Glyptosternum maculatum in order to assist lipid absorption (Xiong et al. 2011). It was observed that more than $30 \%$ of lipid was absorbed between the mid intestines. The lipid absorption agrees with previous studies on European seabass Dicentrarchus labrax, gilthead seabream Sparus aurata (Diaz et al. 1997), flounder Hippoglossus stenolepis (Murray et al. 2003), zebrafish Danio rerio (Anderson et al. 2011) and archerfish Toxotes jaculatrix (Das et al. 2014).

The absorption of carbohydrates was significantly low compared to proteins and lipids. This is due to the fact that the pellet contained relatively low carbohydrate content and lead to lower energy value. This has been observed for example in Asian sea bass Lates calcarifer (Orsod et al. 2012), white bream Blicca bjoerkna (Cara et al. 2003) and black seabream Pagellus bogaraveo (Ribeiro et al. 2008). Besides that, the patterns for energy removal closely followed the pattern for lipids. It is observed that more than $80 \%$ of the food (pellet) energy was expelled through reaching the posterior intestine. Theoretically, the ADC value between food and feces should have been higher as the absorption completes (Das et al. 2014). However, dilution may happen in the experimental water, where the form of feces excreted was in the form of fluid than solid. Although the data from different salinities give generally similar patterns, the higher absorption occurred as the salinity decreased showing that salinity plays role in the nutrient absorption. These studies further showed that exposure of $\mathrm{TG} \times \mathrm{GG}$ hybrid grouper to higher salinity treatments ( 25 and $30 \mathrm{ppt}$ ) affect the absorption of nutrient and the digestibility which consequently affect the growth performance in gilthead seabream Sparus aurata, as described by Moutou et al. (2004). As the intestine plays a major role in osmoregulation (Grosell 2006), salinitymediated decrease in digestibility may therefore be due in part to a higher rate of food movement in fish maintained at high salinities and thus reduce the time required for more complete digestion and absorption of nutrients. These results are in agreement to those reported by Alava (1998) in milkfish, Chanos chanos. Moreover, higher salinity contributes to a higher rate of food movement, lower digestibility and poor nutrient absorption in trouts (Morgan \& Iwama 1991). Marine fish drink water for osmoregulatory process. Possibly, the digestive efficiency and nutrient absorption is compromised in marine fish due to the food motility changes required by this osmoregulatory process (Boeuf \& Payan 2001). Therefore, it was suggested that the digestibility and nutrient absorption might be better if the salinity is manipulated by maintaining the optimum salinity levels in order to increase the digestion process and lead to higher growth rate. In this study, it is suggested that the optimum salinity level is $15 \mathrm{ppt}$ in order for better nutrient absorption in TG×GG hybrid grouper juveniles.

\section{CONCLUSION}

In conclusion, the present study specifies that GET in TGXGG hybrid grouper increase with decreasing salinities (10-20 ppt), however, decrease in comparatively higher salinity range between 25 and 30 ppt. The findings show variation in optimum salinity for absorption of nutrient in TGXGG hybrid grouper juveniles, with decreased salinity was optimum for nutrient absorption. Maximum nutrient absorption was seen at $15 \mathrm{ppt}$. This lead to faster digestion in 15 ppt. Overall, these findings may have important consequences for optimization of commercial production of TGXGG hybrid grouper as better digestion may lead to higher growth performance.

\section{ACKNOWLEDGEMENTS}

The MyBrain 15 scholarship to the first author is gratefully acknowledged. We would like to thank Suk Ling Wee (Subject Editor, Sains Malaysiana) and anonymous reviewer for their very useful comments. This study was funded by Institute of Climate Change, Universiti Kebangsaan Malaysia (UKM) through the research grant GUP-2017-023 to Simon K. Das.

\section{REFERENCES}

Alava, V.R. 1998. Effect of salinity, dietary lipid source and level on growth of milkfish (Chanos chanos) fry. Aquaculture 167(3): 229-236.

Anderson, J.L., Carten, J.D. \& Farber, S.A. 2011. Zebrafish lipid metabolism: From mediating early patterning to the metabolism of dietary fat and cholesterol. Methods in Cell Biology 101: 111-141.

AOAC. 1995. AOAC Official Methods of Analysis. 16th ed. New York: Arlington.

Austreng, E. 1978. Digestibility determination in fish using chromic oxide marking and analysis of contents from different segments of the gastrointestinal tract. Aquaculture 13(3): 265-272.

Boeuf, G. \& Payan, P. 2001. How should salinity influence fish growth? Comparative Biochemistry and Physiology Part C: Toxicology \& Pharmacology 130(4): 411-423.

Borlongan, I.G. 1990. Studies on the digestive lipases of milkfish, Chanos chanos. Aquaculture 89(3-4): 315-325.

Cara, J.B., Moyano, F.J., Cárdenas, S., Fernández-Díaz, C. \& Yúfera, M. 2003. Assessment of digestive enzyme activities during larval development of white bream. Journal of Fish Biology 63(1): 48-58.

Conides, A.J., Parpoura, A.R. \& Fotis, G. 1997. Study on the effects of salinity on the fry of the euryhaline species gilthead 
sea bream (Sparus aurata L. 1758). Journal of Aquaculture in the Tropics 12: 297-304.

Das, S.K., Ghaffar, M.A., Bakar, Y., Brito, M.F., Mastura, S.S. \& Temple, S.E. 2014. X-radiographic observations of food passage and nutrient absorption along the alimentary tract of archerfish, Toxotes jaculatrix. Bulletin of Marine Science 90(4): 903-919.

De, M., Ghaffar, M.A., Bakar, Y. \& Das, S.K. 2016. Effect of temperature and diet on growth and gastric emptying time of the hybrid, Epinephelus fuscoguttatus $\bigcirc \times E$.

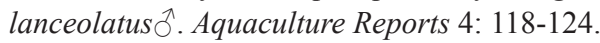

De, M., Mazlan, A.G. \& Simon, K.D. 2014. Temperature effect on gastric emptying of hybrid grouper (Epinephelus spp.). AIP Conference Proceedings 1614(1): 616-618.

Diaz, J.P., Mani-Ponset, L., Guyot, E. \& Connes, R. 1997. Biliary lipid secretion during early post-embryonic development in three fishes of aquacultural interest: Sea bass, Dicentrarchus labrax L., sea bream, Sparus aurata L., and pike-perch, Stizostedion lucioperca (L). Journal of Experimental Zoology 277(5): 365-370.

Eusebio, P.S., Toledo, J.D., Mamauag, R.E.P. \& Bernas, M.J.G. 2004. Digestive enzyme activity in developing grouper (Epinephelus coioides) larvae. In Advances in Grouper Aquaculture, edited by Rimmer, M.A., McBride, S. \& Williams, K.C. Canberra: Australian Center for International Agriculture Research.

Ferraris, R.P., Catacutan, M.R., Mabelin, R.L. \& Jazul, A.P. 1986. Digestibility in milkfish, Chanos chanos (Forsskal): Effects of protein source, fish size and salinity. Aquaculture 59(2): 93-105.

Firdaus-Nawi, M., Zamri-Saad, M., Nik-Haiha, N.Y., Zuki, M.A.B. \& Effendy, A.W.M. 2013. Histological assessments of intestinal immuno-morphology of tiger grouper juvenile, Epinephelus fuscoguttatus. SpringerPlus 2(1): 611-614.

García-Meilán, I., Ordóñez-Grande, B., Machahua, C., Buenestado, S., Fontanillas, R. \& Gallardo, M.A. 2016. Effects of dietary protein-to-lipid ratio on digestive and absorptive processes in sea bass fingerlings. Aquaculture 463: 163-173.

Gisbert, E., Giménez, G., Fernández, I., Kotzamanis, Y. \& Estévez, A. 2009. Development of digestive enzymes in common dentex Dentex dentex during early ontogeny. Aquaculture 287(3-4): 381-387.

Grosell, M. 2006. Intestinal anion exchange in marine fish osmoregulation. Journal of Experimental Biology 209(15): 2813-2827.

Hamre, K., Lukram, I.M., Rønnestad, I., Nordgreen, A. \& Sæle, Ø. 2011. Pre-digestion of dietary lipids has only minor effects on absorption, retention and metabolism in larval stages of Atlantic cod (Gadus morhua). British Journal of Nutrition 105(6): 846-856.

Ikeda, M., Kakizaki, H. \& Matsumiya, M. 2017. Biochemistry of fish stomach chitinase. International Journal of Biological Macromolecules 104: 1672-1681.

Jones, D.B. 1931. Factors for Converting Percentages of Nitrogen in Foods and Feeds into Percentages of Proteins. Washington, DC: US Department of Agriculture.

Lied, E., Julshamn, K. \& Braekkan, O.R. 1982. Determination of protein digestibility in Atlantic cod (Gadus morhua) with internal and external indicators. Canadian Journal of Fisheries and Aquatic Sciences 39(6): 854-861.

Maynard, L.A., Loosli, J.K., Hintz, H.F. \& Warner, R.G. 1979. Animal Nutrition. 7th edition. St. Louis: McGraw-Hill.
Mazlan, A.G. \& Grove, D.J. 2003. Gastric digestion and nutrient absorption along the alimentary tract of whiting (Merlangius merlangus L.) fed on natural prey. Journal of Applied Ichthyology 19(4): 229-238.

Moutou, K.A., Panagiotaki, P. \& Mamuris, Z. 2004. Effects of salinity on digestive protease activity in the euryhaline sparid Sparus aurata L.: A preliminary study. Aquaculture Research 35(9): 912-914.

Morgan, J.D. \& Iwama, G.K. 1991. Effects of salinity on growth, metabolism, and ion regulation in juvenile rainbow and steelhead trout (Oncorhynchus mykiss) and fall chinook salmon (Oncorhynchus tshawytscha). Canadian Journal of Fisheries and Aquatic Sciences 48(11): 2083-2094.

Murray, H.M., Gallant, J.W., Perez-Casanova, J.C., Johnson, S.C. \& Douglas, S.E. 2003. Ontogeny of lipase expression in winter flounder. Journal of Fish Biology 62(4): 816-833.

Orsod, M., Joseph, M. \& Huyop, F. 2012. Characterization of exopolysaccharides produced by Bacillus cereus and Brachybacterium sp. isolated from Asian sea bass (Lates calcarifer). Malaysian Journal of Microbiology 8(3): 170174.

Partridge, G.J. \& Jenkins, G. I. 2002. The effect of salinity on growth and survival of juvenile black bream (Acanthopagrus butcheri). Aquaculture 210(1-4): 219-230.

Ribeiro, L., Couto, A., Olmedo, M., Álvarez-Blázquez, B., Linares, F. \& Valente, L.M. 2008. Digestive enzyme activity at different developmental stages of blackspot seabream, Pagellus bogaraveo (Brunnich 1768). Aquaculture Research 39(4): 339-346.

Singhabun, A. \& Kummee, W. 2015. Effect of density, feeding frequency and salinity on growth and survival rate of juvenile giant grouper (Epinephelus lanceolatus Bloch, 1790). Aquaculture International 23: 671-682.

Specziar, A. 2002. In situ estimates of gut evacuation and its dependence on temperature in five cyprinids. Journal of Fish Biology 60(5): 1222-1236.

Su-Jiu, W., Hai-Fa, Z., Jun, Z., Yu-Qing, Y. \& Shao-Sen, Y. 2011. Effects of different salinities on growth and physiology of orange-spotted grouper, Epinephelus coioides. Journal of Guangdong Ocean University 6: 7-10.

Sutthinon, P., Thongprajukaew, K., Saekhow, S. \& Ketmanee, R. 2015. Juvenile hybrid grouper (Epinephelus coioides $\times E$. lanceolatus) are euryhaline and can grow in a wide range of salinities. Aquaculture International 23(2): 671-682.

Temming, A. \& Herrmann, J.P. 2001. Gastric evacuation in horse mackerel. I. The effects of meal size, temperature and predator weight. Journal of Fish Biology 58(5): 1230-1245.

Vinagre, C., Maia, A. \& Cabral, H.N. 2007. Effect of temperature and salinity on the gastric evacuation of juvenile sole Solea solea and Solea senegalensis. Journal of Applied Ichthyology 23(3): 240-245.

Wetherbee, B.M,Gruber, S.H. \& Ramsey,A. 1987.X-radiographic observations of food passage through digestive tracts of lemon sharks. Transactions of the American Fisheries Society 116(5): 763-767.

Wuenschel, M.J. \& Werner, R.G. 2004. Consumption and gut evacuation rate of laboratory-reared spotted seatrout (Sciaenidae) larvae and juveniles. Journal of Fish Biology 65(3): 723-743.

Xin, L., Xiaoyun, H., Yunbo, L., Guoying, X., Xianbin, J. \& Kunlun, H. 2008. Comparative analysis of nutritional composition between herbicide-tolerant rice with bar 
gene and its non-transgenic counterpart. Journal of Food Composition and Analysis 21(7): 535-539.

Xiong, D.M., Xie, C.X., Zhang, H.J. \& Liu, H.P. 2011. Digestive enzymes along digestive tract of a carnivorous fish Glyptosternum maculatum (Sisoridae, Siluriformes). Journal of Animal Physiology and Animal Nutrition 95(1): 56-64.

Zambonino-Infante, J.L., Mazurais, D., Dubuc, A., Quéau, P., Vanderplancke, G., Servili, A., Cahu, C., Le Bayon, N., Huelvan, C. \& Claireaux, G. 2017. An early-life hypoxia event has a long-term impact on protein digestion and growth in juvenile European sea bass. Journal of Experimental Biology 220(10): 1846-1851.

Noorashikin Md Noor, Simon Kumar Das* \& Zaidi Che Cob School of Environmental and Natural Resource Sciences Faculty of Science and Technology

Universiti Kebangsaan Malaysia 43600 UKM Bangi, Selangor Darul Ehsan Malaysia
Simon Kumar Das* \& Zaidi Che Cob Marine Ecosystem Research Center Faculty of Science and Technology Universiti Kebangsaan Malaysia 43600 UKM Bangi, Selangor Darul Ehsan Malaysia

Mazlan Abd. Ghaffar Institute of Oceanography and Environment Universiti of Malaysia Terengganu 21030 Kuala Nerus, Terengganu Malaysia

*Corresponding author; email: simon@ukm.edu.my

Received: 10 July 2017

Accepted: 1 February 2018 